\title{
Chronic infection during placental malaria is associated with up-regulation of cycloxygenase-2
}

\author{
Demba Sarr ${ }^{1}$, Delphine Aldebert ${ }^{1}$, Laurence Marrama ${ }^{1}$, Emilie Frealle ${ }^{1}$, Alioune Gaye ${ }^{2}$, Hamoud O Brahim , \\ Makhtar Niang ${ }^{1}$, Jean Marie Dangou', Odile Mercereau-Puijalon ${ }^{3}$, Jean Yves Lehesran ${ }^{4}$, Ronan Jambou ${ }^{1,5^{*}}$
}

\begin{abstract}
Background: Placental malaria (PM) is associated with poor foetal development, but the pathophysiological processes involved are poorly understood. Cyclooxygenase (COX) and lipoxygenase (LOX) which convert fatty acids to prostaglandins and leukotrienes, play important roles in pregnancy and foetal development. COX-2, currently targeted by specific drugs, plays a dual role as it associates with both pre-eclampsia pathology and recovery during infection. The role of COX during PM was questioned by quantifying at delivery COX-1, COX-2, 15-LOX, and IL-10 expression in two groups of malaria infected and uninfected placenta.

Methods: Placental biopsies were collected at delivery for mRNA isolation and quantification, using real time PCR.

Results: COX-2 and IL-10 mRNAs increased mainly during chronic infections (nine- and five-times, respectively), whereas COX-1 transcripts remained constant. COX-2 over-expression was associated with a higher birth weight of the baby, but with a lower rate of haemoglobin of the mother. It was associated with a macrophage infiltration of the placenta and with a low haemozoin infiltration. In the opposite way, placental infection was associated with lower expression of 15-LOX mRNA. A high degree of haemozoin deposition correlates with low birth weight and decreased expression of COX-2.

Conclusion: These data provide evidence that COX-2 and IL-10 are highly induced during chronic infection of the placenta, but were not associated with preterm delivery or low birth weight. The data support the involvement of COX-2 in the recovery phase of the placental infection.
\end{abstract}

\section{Background}

In Africa, most of the malaria mortality and morbidity is borne by children and pregnant women with an estimate 200,000 infant deaths each year as a result of malaria infection in pregnancy [1]. During placental malaria (PM) parasites accumulate in the placenta with an increased risk of low birth weight (LBW) [2]. This accumulation can be related to low blood flow through the placenta and to specific adhesion of infected red blood cells (IRBCs) on syncytiotrophoblast. This adhesion is mediated by chondroitin sulphate A and specific var antigens. Monocytes also accumulate in the intervillous space of the placenta [3] mostly attracted by release of MIF [4,5]. Pro-inflammatory cytokine release also associates with this accumulation of parasites, pigment, and monocytes in the tissue [6,7].

\footnotetext{
* Correspondence: rjambou@pasteur.fr

${ }^{1}$ Institut Pasteur de Dakar PoBox 220 Dakar, Senegal
}

Decreased blood flow in the placenta is the major factor triggering LBW, which had previously been linked to a modulation of placental cytokine expression [7]. In this context, prostaglandins (PGs) are important modulators of vascular perfusion and fever [8]. Conversion of arachidonic acid to PGs is catalyzed by two isoforms of cyclooxygenase (COX-1 and COX-2) [9]. COX-2-generated PGs are important in inflammation and host defence and is up-regulated prior to the onset of labour $[10,11]$. Whereas COX-1-generated PGs is implicated in homeostasis and survival of the foetus, and mainly secreted in decidual lining of the uterus $[12,13]$ without modulation during gestation or labour. The role of COX-1 and -2 during placental pathology was suspected some time ago when bacterial lipopolysaccharide mediated foetal death was related to an over-production of COX-2 [14]. In the same line COX-2 over expression was reported during pre-eclampsia [15], but not after this episode [16] and was associated with apoptosis in

(c) 2010 Sarr et al; licensee BioMed Central Ltd. This is an Open Access article distributed under the terms of the Creative Commons 
smooth chorion trophoblast cells of human foetal membrane tissues [17]. This enhancement seems to be triggered by leukocyte microparticles $[15,18]$. However, Khan et al published conflicting results describing a reduction of COX-2 and of the amount of NHE-1 in pre-eclamptic placentas with an unaltered level of COX1 [19].

During placental malaria, modulation of these PGs pathway could play a role in preterm delivery and low birth weight as observed during pre-eclampsia. A foetal COX-2 gene polymorphism was associated with placental malperfusion during placental malaria [20]. In the general, circulation PGE2 and blood mononuclear cell COX-2 expression were also reported to be inversely related with disease severity in children with malaria [21,22].

Two other arachidonic acid pathways, the epoxide and the lipoxygenase (LOX) pathway [23], are involved in pathology during pregnancy [24]. LOX leads to synthesis of leukotrienes and lipoxins with immune and antiinflammatory activity. Three enzymes control this pathway: 5-LOX produced by neutrophils, 12-LOX produced by platelets, and 15-LOX located in macrophages and endothelia. 15-LOX is highly inducible and produces hydroxyeicosatetraenoic (HETE) compounds [25]. Interestingly, 15-HETE is a powerful inhibitor of pro-inflammatory eicosanoids, whereas 5-HETE and 12-HETE are chemotactic factors for neutrophils and they also stimulate vasodilation through PG synthesis [26].

Eicosanoids are thus powerful regulators of placenta perfusion and overall of the pregnancy outcome. New analgesic and anti-inflammatory drugs, inhibitors of COX activity, are often used in malaria endemic areas to reduce fever, pain, and inflammation [27]. They can interfere with PGs regulations and modulate the outcome of the pregnancy even if antenatal administration of celecoxib (a COX-2 inhibitor) seems to improve placental perfusion in the pregnant rabbit [28]. All these data pave the way of new studies to understand the pathophysiology of placental malaria, and this study was designed to address the role of these enzymes during $\mathrm{PM}$ in low malaria transmission area. The purpose of this study was to evaluate the levels of COX-1, COX-2, and 15-LOX mRNA genes in human placenta infected by $P$. falciparum compared to uninfected placenta. Although delivery is only an instant in the whole pregnancy, it is however a good snapshot of the placenta statement. Studies conducted at delivery also give information on the late stage of the mother-baby interaction.

\section{Methods}

\section{Placenta collection}

Collection of placentas was done at delivery, at the maternity ward the Centre de Santé Roi Baudoin,
Guediawaye, Dakar Sénégal. Details regarding enrolment and standard laboratory procedures have been reported elsewhere [29]. It involved women, more than 16 years, with an uncomplicated delivery of live newborns. For all women giving informed consent, an immuno-chromatography test (ICT, PfHRP2 MaKromed) was carried out on placental blood. A standard questionnaire was used to record information including: mother's age, gravidity, gestational age (determined by the date of the last menstrual period and morphometric measurement of the uterus during antenatal clinic visits) and history of malaria attacks. Babies and placentas were weighed immediately after birth. Gender and Apgar scores were recorded. LBW was defined as $<2,500 \mathrm{~g}$, and prematurity as gestational age $<37$ weeks. Women with haemoglobin $(\mathrm{Hb})$ less than $11 \mathrm{~g} / \mathrm{dl}$ were considered anaemic.

The HIV infection status of the participants was not established at the time of the study however, HIV seroprevalence in Senegalese population was low $(0.8 \%$ of parturients in Dakar) [30]. All ICT-positive women received chloroquine after delivery. Anaemic women received iron and folic acid supplements.

After collection, whole placentas were refrigerated until assessment (less than two hours after delivery). For each placenta, four biopsies were sampled [31], rinsed in phosphate buffer saline (PBS), rapidly frozen in liquid nitrogen and stored at $-80^{\circ} \mathrm{C}$ until RNA extraction. An additional four biopsies were sampled for histology and immunohistochemistry studies.

\section{Histology and immunohistochemistry}

Immediately after collection, samples for histology and immunohistochemistry were fixed in $4 \%$ buffered paraformaldehyde and processed as previously described [29]. $5 \mu \mathrm{m}$ cryosections were stained either with haematoxylin-eosin (H\&E) or with May-Grünewald-Giemsa (MGG). Quantification of parasites was done in placenta for 100 fields (magnification 1000x) of MGG stained sections and in blood by examination of Giemsa-stained thick smears. Haemozoin (HZ) was identified on sections as brown granular material with high refringence on polarization microscope, which differentiates then from formalin crystals. Contain in $\mathrm{HZ}$ was qualitatively assessed on sections as: no HZ, low HZ (1-2 crystals/ field at $\times 1000)$ or high $\mathrm{HZ}$ (> 2/field).

Acute infections (AI) were defined by the presence of parasites on sections without malaria pigment, chronic infections (CI) by presence of parasites and pigment, and past infections (PI) by the presence of pigment alone. PfHRP2+ placentas with no evidence of parasites or pigment were classified as "no-parasite" (NP). For the control group all PfHRP2 rapid diagnosis test, parasites and pigment detection were negative in placenta and in the venous blood. 
For immunochemistry, after blocking endogenous peroxidases and non-specific binding, tissue sections were incubated for $1 \mathrm{~h}$ at room temperature with primary antibodies or control isotypes and revealed using LSAB detection kit (DakoCytomation). Antibodies used were CD68 (PG-M1), and HLA-DR (TAL.1B5) from DakoCytomation mouse antibodies against. The number of cells in the intervillous space was counted over 100 fields (magnitude $\times 400$ ).

\section{mRNA quantification}

Frozen biopsies were ground into powder in liquid nitrogen before homogenization in $4 \mathrm{M}$ guanidium buffer. RNAs were extracted using standard phenol-chloroform procedure, precipitated with isopropanol and washed before quantification. Integrity of total RNA was assessed on an ethidium bromide (EtBr) stained denaturing agarose gel. For reverse transcription $2 \mu \mathrm{g}$ of RNA was denatured at $65^{\circ} \mathrm{C}$ for $10 \mathrm{~min}$, cooled on ice-water, and reverse-transcribed for $60 \mathrm{~min}$ at $43^{\circ} \mathrm{C}$ with $40 \mathrm{U} / \mu \mathrm{l}$ RNase inhibitor and oligo-dT. Amplification was performed in an ABI Prism 7000 Sequence Detection System using Taqman Universal PCR Master Mix (PE Biosystems), containing $300 \mathrm{nM}$ of primers and $200 \mathrm{nM}$ of fluorogenic probes. Each measurement was carried out in duplicate and amplification of Peptidyl Propyl Isomerase A (PPIA, also called Cyclophylin A) was conducted on the same plate. Others housekeeping genes such as beta2-microglobulin and beta-actin were run together with PPIA, but were not selected for standardization as less constant between infected and uninfected placentas. Probes and primers (Table 1) were designed using Primer Express software (Applied Biosystems). Cycling conditions started at $50^{\circ} \mathrm{C}$ for 2 minutes followed by $95^{\circ} \mathrm{C}$ for 10 minutes, then 40 cycles of $95^{\circ} \mathrm{C}$ for 15 seconds and $60^{\circ} \mathrm{C}$ for 1 minute. The specificity of PCR amplifications was confirmed for each set of primers by sequencing of the PCR product and primers specificity was confirmed by single peaks demonstrated by dissociation curves after amplification of cDNA. The amplification efficiency was assessed for all the genes by amplifying serial dilutions of cDNA, and calculation of the slope (delta $\mathrm{Ct}) /(\log \mathrm{cDNA}$ dilution) which must be less than 0.1. Quantification of gene expression was done according to Livak et al [32] using for each gene the mean Ct-values of the duplicate. For each sample the results were adjusted according to the level of PPIA in the same sample. The PfHRP2-negative control group was used to normalize the results. For each gene, the relative quantity (RQ) of mRNA was expressed, in arbitrary units, as a fold increase in comparison with the control group.

\section{Statistical analysis}

Differences between groups were compared using Mann-Whitney U test (MW) for two groups or with
Kruskal-Wallis test (KW) and Median test for more than two. Correlations were calculated using a Spearman $\mathrm{R}$ test (SP). Alpha risk was set at 0.05 .

\section{Results}

Chronic infection is associated with lower birth weight

During this study, 692 pregnant women were examined among whom 71 had a Plasmodium falciparum histidine rich protein positive-RDT (PfHRP2+) (10.3\%). For these PfHRP2+ women, $25 \%$ of the babies had LBW and $67 \%$ of the women were anaemic [29]. Compared to the control women, chronicactive infections were associated with lower birth weight ( $\mathrm{p}<0.008$ and $\mathrm{p}<0.0002$ respectively) as well as CI and PI correlated with lower haemoglobin levels ( $\mathrm{p}<0.05$ for both). No significant change was found for birth weight and haemoglobin, according to parity may be due to the low sample size of the study. For the purpose of this study, 54 placental samples were randomly selected from the different histological groups after classification (table 2). Among the selected PfHRP2+ women, 13 were primiparous, 13 secundiparous, and 14 multiparous.

\section{Past and chronic infections are associated with a higher level of COX-2 and IL-10 mRNA}

COX-2 mRNA increased during PM especially during late stage of the infection: 9.0, 5.4, 3.8 and 3-time higher in placentas with $\mathrm{CI}, \mathrm{AI}, \mathrm{PI}$ and NP, respectively, than in the control group ( $p<0.01 \mathrm{MW}$ for $\mathrm{CI}$ and $\mathrm{AI}$ ). The expression of COX-1 remained low in all the placentas without significant differences between PfHRP2- (Ctrl) and PfHRP2+ (CI, AI, PI \& NP) groups, but trends to increase during past infection (Figure 1A).

Because IL-10 has been shown to exert direct regulatory effects on prostaglandin production, we also measured IL-10 mRNA in our placental samples. The levels of IL-10 transcripts were higher in PfHRP2+-placentas than in controls (MW $\mathrm{p}=0.004$, Figure $1 \mathrm{~A}$ ) and correlated with COX-2 expression $(\mathrm{n}=54, \mathrm{SP} \mathrm{p}=0.006 \mathrm{R}=$ 0.36 ; and $\mathrm{p}=0.008 \mathrm{R}=0.36$ ). However none of these markers correlated with the parasitaemia. In the opposite way 15-LOX was lower in PfHRP2+-placentas than in controls (MW $\mathrm{p}=0.0002$ ) (Figure $1 \mathrm{~A}$ ), but correlates with parasitaemia in the placenta $(\mathrm{SP} R=0.416, \mathrm{p}=$ 0.0076) and with COX-2 mRNA expression (SP p = $0.018, \mathrm{R}=0.37$ ).

The levels of COX-2 mRNA but not of COX-1, 15LOX, and IL-10, trend to decrease when parity increased (Figure 1B), but there was no significant difference for any of these genes according to duration of the pregnancy or with the presence of fever at delivery. 
Table 1 Nucleotides sequences of the primers and probes used for real time PCR. PPIA: Peptidyl Propyl Isomerase A.

\begin{tabular}{|c|c|c|c|}
\hline Human Gene & Accession number & $\begin{array}{c}\text { Sequences } \\
\text { (a: Probe, b: Primer F, c: primer R) }\end{array}$ & Amplicon size (bp) \\
\hline $\operatorname{coX}-1$ & NM_000962 & $\begin{array}{l}\text { a) Fam-CTG GCC TCA GCA CTC TGG AAT GAC AA-Tamra } \\
\text { b) ATG ATG GGC CTG CTG TGG A } \\
\text { c) CCA ACA CTC ACC ATG CCA AAC }\end{array}$ & 150 \\
\hline $\operatorname{cox}-2$ & NM_000963 & $\begin{array}{l}\text { a) Fam-TGC CCA GCA CTT CAC GCA TCA GTT-Tamra } \\
\text { b) GCT CAA ACA TGA TGT TTG CAT TC } \\
\text { c) GCT GGC CCT CGC TTA TGA }\end{array}$ & 79 \\
\hline 15-LOX & NM_001140 & $\begin{array}{l}\text { a) Fam-TCC ACC AGG CTT CTC TCC AGA TGT CC-Tamra } \\
\text { b) GGA GAC AGT GAT GGC GAC ACT } \\
\text { c) TCT GCC CAG CTG CCA AGT }\end{array}$ & 74 \\
\hline PPIA & NM_021130 & $\begin{array}{l}\text { a)Fam-AGC TCA AAG GAG ACG CGG CCC A-Tamra } \\
\text { b) GTC AAC CCC ACC GTG TTC TT } \\
\text { c) CTG CTG TCT TTG GGA CCT TGT }\end{array}$ & 73 \\
\hline $\mid \mathrm{L}-10$ & NM_000572 & $\begin{array}{l}\text { a)Fam-CAG GCA ACC TGC CTA ACA TGC TTC-Tamra } \\
\text { b) TGA GAA CAG CTG CAC CCA CTT } \\
\text { c) ATC TCC GAG ATG CCT TCA GC }\end{array}$ & 70 \\
\hline
\end{tabular}

Elevated level of COX-2 is associated with anaemia in the mother but not with low birth weight

Birth weight was significantly lower in primiparous than in secundiparous or multiparous (MW $\mathrm{p}<0.05$ for both). It was also lower during $\mathrm{AI}$ and $\mathrm{CI}$ than in control group. However, women who delivered babies with normal birth weight had higher level of COX-2 transcripts compared to others (MW $\mathrm{p}<0.02$; Figure $2 \mathrm{~B}$ ). In the opposite way COX-1 and 15-LOX transcripts trend to increase in association with LBW (respectively 2 and 1 fold increase than for the normal birth weight group, NS Figure 2B).

Haemoglobin was inversely related to the level of COX-1, COX-2 and IL-10 but increased with 15-LOX (SP R $=-0.58,-0.57,-0.51,0.48$ respectively, $\mathrm{p}<0.001$ for each) (Figure 2A). Haemoglobin tends to decrease with the amount of $\mathrm{HZ}$ in the placenta (Figure 3A, middle panel; NS). Anaemia was thus associated with an increase of COX-2 and with PI (MW p $<0.001$, with control group).

COX-2 expression increase with macrophage recruitment and with decrease of pigment deposit

High level of pigment in the placenta was associated with significantly lower birth weight $(\mathrm{KW} p=0.013, \mathrm{n}=$ 44, Figure 3A, left panel), and with lower haemoglobin level in the mother (KW p $=0.018$, Figure $3 \mathrm{~A}$, middle panel). However lower pigment density associated with a higher level of COX-2 and IL-10 transcripts (Figure $3 \mathrm{~d})$, without significant change for COX-1 (MW, p < 0.001 for both).

As detected by immunohistochemistry (Figure 3c), macrophages (CD68+) and activated HLADR+ presenting cells increased in PfHRP2+-placenta $(p<0.001$ for both, DNS), mainly during late infection (CI or PI versus Ctrl: MW $\mathrm{p}<0.001)$. Primiparous and

Table 2 Clinical and laboratory data of enrolled women according to the class of infection.

\begin{tabular}{|c|c|c|c|c|c|c|}
\hline Variables & $\begin{array}{c}\text { Ctrl } \\
\text { (PfHRP2-) }\end{array}$ & $\begin{array}{c}\text { Total } \\
\text { (PfHRP2+) }\end{array}$ & NP & Past I & Acute I & Chronic I \\
\hline No. of women & 14 & 40 & 10 & 10 & 10 & 10 \\
\hline Primigravidae n (\%) & $4(28)$ & $13(32.5)$ & $3(30)$ & $3(30)$ & $3(30)$ & $4(40)$ \\
\hline Secundigravidae n (\%) & $5(36)$ & $13(32.5)$ & $3(30)$ & $3(30)$ & $3(30)$ & $3(30)$ \\
\hline Multigravidae n (\%) & $5(36)$ & $14(35)$ & $4(40)$ & $4(40)$ & $4(40)$ & $3(30)$ \\
\hline Age (years) & $24.6 \pm 1.6$ & $25.6 \pm 1.13$ & $25.2 \pm 2.3$ & $26.6 \pm 0.6$ & $26.0 \pm 1.96$ & $24.8 \pm 2.3$ \\
\hline Pregnancy duration, weeks & $40.8 \pm 1.2$ & $40.5 \pm 2.6$ & $41.1 \pm 1.1$ & $40.9 \pm 0.9$ & $41.1 \pm 1.1$ & $41.3 \pm 1.3$ \\
\hline Birth weight (g) & $3,153 \pm 93$ & $2,723 \pm 93^{*}$ & $2,995 \pm 137$ & $2,623 \pm 131^{*}$ & $2,862 \pm 167$ & $2,411 \pm 251^{*}$ \\
\hline Haemoglobin (g/dl) & $11.9 \pm 0.3$ & $9.4 \pm 2.5^{*}$ & $10.2 \pm 1.2$ & $8.5 \pm 0.4^{*}$ & $8.4 \pm 1.1^{*}$ & $10.2 \pm 0.9$ \\
\hline Parasitaemia, Venous & 0 & $83 \%$ & 0 & 0 & $205.5 \%$ & $35.3 \%$ \\
\hline Parasitaemia, Placental & 0 & $294 \%$ & 0 & 0 & $644.5 \%$ & $\%$ \\
\hline
\end{tabular}

$\left(^{*}\right)$ means significant when compared with the control group $(p<0.05)$

NP (no parasites): PfHRP2 positive placenta without parasites or pigment detected by microscopy; PI (past infection): only pigment detected by microscopy; Al (acute infection): only parasites detected; $\mathrm{Cl}$ (chronic infection): parasites and pigment detected; control (Ctrl): uninfected women with PfHRP2 negative placenta. Data are mean \pm SE. Parasitaemia are expressed as parasites per 100 leukocytes. $\left(^{*}\right)$ significant difference with control group ( $p<0.01$ Mann Whitney $U$ test). 


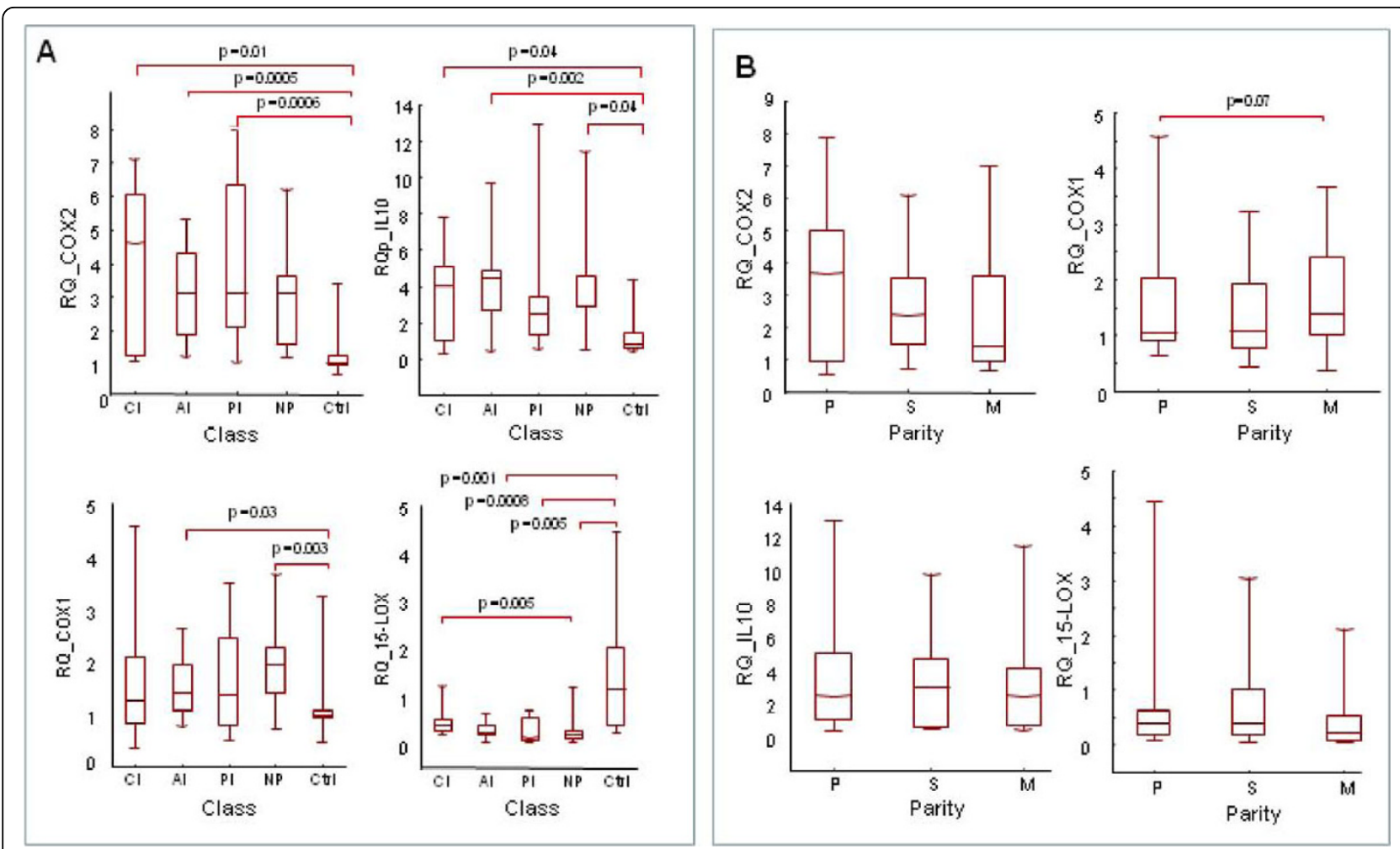

Figure 1 Expression of COX-1, COX-2, 15-LOX and IL-10 mRNA in placenta. Expression levels was calibrated for each gene using PPIA as housekeeping gene (delta $\mathrm{Ct}=\mathrm{Ctgene}-\mathrm{CtPPIA}$ ) and normalized using the pool of uninfected control placentas (delta delta $\mathrm{Ct}=$ delta $\mathrm{Ct}$ mean delta Ct (ctrl)). Results are plotted according to: (A) infection classes: $\mathrm{Cl}=$ Chronic Infections, $\mathrm{Al}=\mathrm{Acute}$ Infections, $\mathrm{PI}=\mathrm{Past}$ Infections, NP $=$ No parasites/pigment detectable, $C$ trl $=$ uninfected placentas (PfHRP2-) (B) Parity: $\mathrm{P}=$ primiparous, $\mathrm{M}=$ multiparous, and $\mathrm{S}=$ secondiparous women. $R Q=$ Relative Quantity $=2^{- \text {(deltadelta } C t)}$. P value are indicated for significant test only $(p<0.05)$.

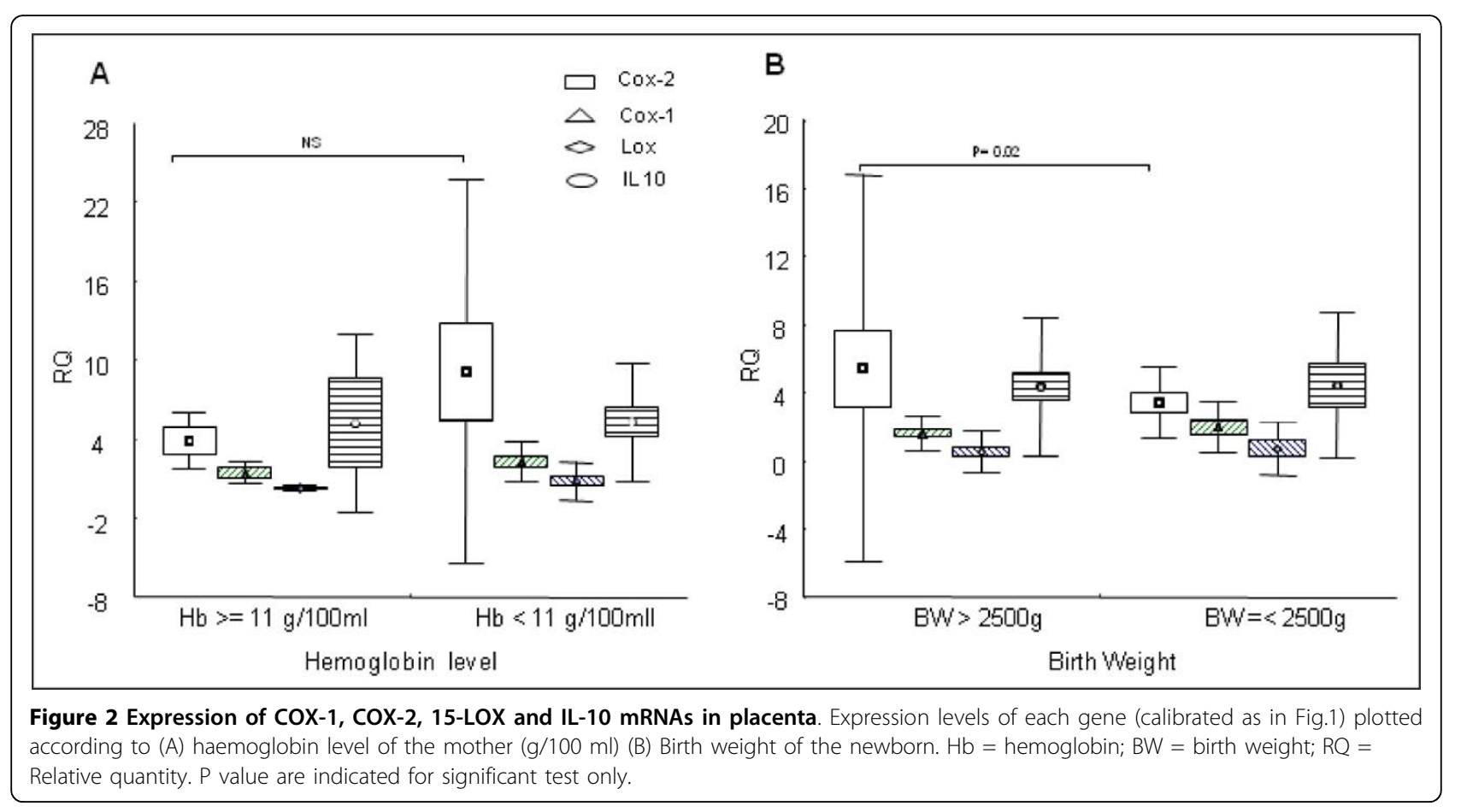




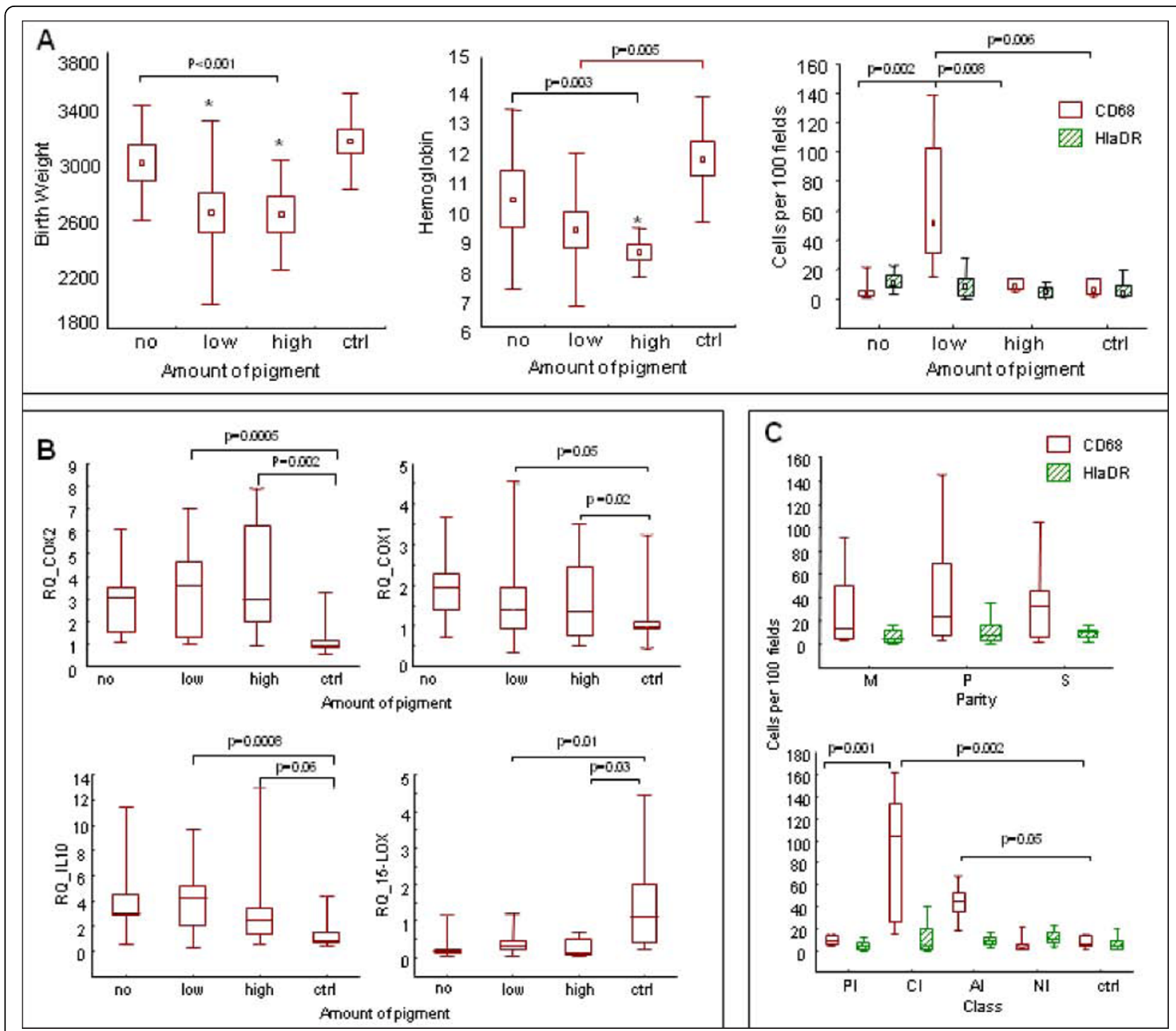

Figure 3 Impact of the charge of pigment in the placenta. For PfHRP2+ placenta, the pigment deposit was plotted as: "no pigment" (No); "low load of pigment" (low) for less than 3 pigments for 10 field ( $\times 400)$; "high load of pigment" (high) for more than 3 pigments per field; "control group" (Ctrl) for PfHRP2- placenta. A) Relation between charge in pigment and birth weight of the newborn (g), B) Relation between charge in pigment and haemoglobin level of the mother $(\mathrm{g} / 100 \mathrm{ml})$, C) Relation between charge in pigment and count of CD68+ and HLA-DR cells in the placenta (number of cells/100 fields at magnification $\times 400$ ). D) Relation between charge in pigment and expression level of the four genes $(\mathrm{RQ}=$ Relative Quantity $=2$-(deltadelta $\mathrm{Ct}))$. NS = not significant, $\left(^{*}\right)$ means significant when compared with the control group.

secondiparous women exhibited higher levels of CD68+ cells when compared to multiparous $(\mathrm{p}<0.05)$ while CI had significantly higher levels of CD68+ cells compared to PfHRP2- or control ( $\mathrm{p}=0.002)$. The density of macrophages (CD68) increased in the placenta when the amount of pigment was low (median test $\mathrm{p}<0.0001$ ). The count of macrophage was significantly correlated with COX-2 (SP $\mathrm{p}=0.014, \mathrm{R}=0.331), \mathrm{IL}-10$ (SP $\mathrm{p}=$ $0.014, \mathrm{R}=0.332$ ) and 15-LOX mRNA (SP $\mathrm{p}=0.0003, \mathrm{R}$ $=0.539)$. In the placental tissue sections COX-1 protein was detected by immunolabelling in trophoblasts, mononuclear interstitial cells and, most often, in foetal endothelial cells. COX-2 and 15-LOX were mainly detected in macrophages, endothelial cells and trophoblasts. During past and chronic infection, COX-2 was highly expressed in trophoblasts (Sarr, personal communication).

\section{Discussion}

This study is part of a project conducted on the pathophysiology of PM in West African urban areas. Despite the low transmission rate of malaria, a high prevalence 
of PM was observed in this area [29], but its pathogenesis is still poorly understood.

As previously described [11] COX-1 expression remained low in all the samples of our study, in comparison with COX-2. COX-2 expression clearly increased after long-term malaria active infection (CI) of the placenta. Consistent with previous reports [3], chronic infection was associated with a macrophage infiltration of the placenta, which correlated with COX2 over-expression. In placenta COX-2 was mainly detected in macrophages, vascular lymphocytes and fibroblasts [16], which can explain this correlation. These data indicate that low amount of pigment was associated with the highest levels of COX-2 and IL-10 transcripts, whereas, high amount of $\mathrm{HZ}$ was associated with a lower COX-2 expression. In the same line, women with high amount of $\mathrm{HZ}$ had babies with lower birth weights and lower level of haemoglobin. This is in line with data showing inhibition of intervillous blood mononuclear cells (IVBMCs) charged in $\mathrm{HZ}$ and in particular suppression of PGE2, TNF, and IL-10 secretion $[33,34]$. This phagocytosis of haemozoin was reported i) to enhance matrix metalloproteinase- 9 activity and TNF production in human monocytes [35,36], and ii) to reduce immune response by an activation of a Toll-like receptor 9 mediates mechanism [37]. Overall a low charge in $\mathrm{HZ}$ could be a signal to attract macrophages and stimulates cells whereas a high charge could inhibit them.

All these data are consistent with an inflammatory process $[3,38]$. However, COX-2 (unrelated to the term of the pregnancy) was positively correlated with the birth weight, which supports a protective role of this process for the foetus development. Macrophages can also participate in this protective role, as well as prostacyclins secreted by chorion endothelium, which are known to induce relaxing of foetal vasculature [26]. High level of COX-2 was also previously associated with recovery from anaemia [39]. Along the same lines, IL-10 mRNA was significantly higher in infected placentas compared to uninfected ones, as previously described $[40,41]$. High level of IL-10 could be deleterious, as IL10 is known to inhibit COX-2 expression in preterm human placenta [42] and secretion of inflammatory cytokines by monocytes [43]. It was also associated with high parasitaemia, severe anaemia and a low level of COX-2 in PBMC $[8,22]$.

However this could not be relevant during PM as i) COX-2 seems mainly expressed by placenta and not by PBMC and as ii) the effect of IL10 on COX-2 and PGE2 seems to be different in preterm and in term placentas [42]. In the same line, IFN-gamma and oestrogen receptor-beta modulates COX-2 expression in human placental villous endothelial cells $[44,45]$ and need to be measured.

Interestingly, 15-LOX expression correlated with the presence of parasites in the intervillous space, which is consistent with study stating that 15-HETE and 15HPETE stimulated red blood cell adhesion to endothelium [46]. However 15-LOX mRNA expression remained lower in infected samples compared to uninfected or control samples, which can exclude its role in the sequestration of parasites in the placenta.

\section{Conclusion}

In summary, this study showed that COX-2 and IL-10 are highly expressed in active PM. COX-2 correlates with macrophage infiltration and is related to a better outcome of the pregnancy with higher birth weight. All these data support the increase of COX-2 as a witness of placental defence against infection and draw attention on uncontrolled use of anti-COX2 during placental malaria.

\section{Abbreviations}

PM: placental malaria; COX: cyclooxygenase; LOX: lipooxygenase; LBW: low birth weight; ICT: immunochromatographic test; RDT: rapid diagnosis test; HZ: hemozoin; PBMC: peripheral blood mononuclear cell; Cl: Chronic infection; Al: acute infection; PI: past infection; NP: No parasite and pigment (PfHRP2+); PfHRP: Plasmodium falciparum histidine rich protein.

\section{Acknowledgements}

We thank the medical staff of Centre de Sante Roi Baudoin, Guediawaye, for their help during this study, and the women who agreed to participate. This study was supported by the Louis D. Foundation (Académie des Sciences, Paris, France), the RESMAL-chip programme (UE) and FSP-RAl programme (Ministère français des Affaires étrangères). D Sarr was supported by a grant from FSP-RAI and E Frealle by a grant from the "Fondation de la Jeunesse Internationale"

\section{Author details}

${ }^{1}$ Institut Pasteur de Dakar PoBox 220 Dakar, Senegal. ${ }^{2}$ Centre de Santé Roi Baudoin, Guediawaye, Dakar, Senegal. ${ }^{3}$ Institut Pasteur, CNRS URA 2581, Paris, France. ${ }^{4}$ UR10, Mother \& Child Unit, IRD PoBox 1386 Dakar, Senegal.

${ }^{5}$ Département de Parasitologie-Mycologie, Institut Pasteur, Institut Pasteur, 28 rue Dr Roux, 75015 Paris, France.

\section{Authors' contributions}

RJ conceived the study. DS and EF performed the experiments. DS, LM, JMD and RJ analysed the data. DS and RJ wrote the manuscript. DA and LM helped revise it. All authors read and approved the final manuscript.

\section{Competing interests}

The authors declare that they have no competing interests.

\section{Received: 7 October 2009}

Accepted: 9 February 2010 Published: 9 February 2010

\section{References}

1. Steketee RW, Nahlen BL, Parise ME, Menendez C: The burden of malaria in pregnancy in malaria-endemic areas. Am J Trop Med Hyg 2001, 64(1-2 Suppl):28-35.

2. Menendez C, Ordi J, Ismail MR, Ventura PJ, Aponte JJ, Kahigwa E, Font F, Alonso PL: The impact of placental malaria on gestational age and birth weight. J Infect Dis 2000, 181:1740-1745. 
3. Ordi J, Menendez C, Ismail MR, Ventura PJ, Palacin A, Kahigwa E, Ferrer B, Cardesa A, Alonso PL: Placental malaria is associated with cell-mediated inflammatory responses with selective absence of natural killer cells. J Infect Dis 2001, 183:1100-1107.

4. Abrams ET, Brown H, Chensue SW, Turner GD, Tadesse E, Lema VM, Molyneux ME, Rochford R, Meshnick SR, Rogerson SJ: Host response to malaria during pregnancy: placental monocyte recruitment is associated with elevated beta chemokine expression. J Immunol 2003, 170:2759-2764.

5. Chaisavaneeyakorn S, Moore JM, Othoro C, Otieno J, Chaiyaroj SC, Shi YP, Nahlen BL, Lal AA, Udhayakumar V: Immunity to placental malaria. IV. Placental malaria is associated with up-regulation of macrophage migration inhibitory factor in intervillous blood. J Infect Dis 2002, 186:1371-1375.

6. Fried M, Muga RO, Misore AO, Duffy PE: Malaria elicits type 1 cytokines in the human placenta: IFN-gamma and TNF-alpha associated with pregnancy outcomes. J Immunol 1998, 160:2523-2530.

7. Moormann AM, Sullivan AD, Rochford RA, Chensue SW, Bock PJ, Nyirenda T, Meshnick SR: Malaria and pregnancy: placental cytokine expression and its relationship to intrauterine growth retardation. J Infect Dis 1999, 180:1987-1993.

8. Vane JR, Bakhle YS, Botting RM: Cyclooxygenases 1 and 2. Annu Rev Pharmacol Toxicol 1998, 38:97-120.

9. Appleton I, Tomlinson A, Willoughby DA: Induction of cyclo-oxygenase and nitric oxide synthase in inflammation. Adv Pharmacol 1996, 35:27-78.

10. Serdar Z, Gur E, Develioglu O, Colakogullari M, Dirican M: Placental and decidual lipid peroxidation and antioxidant defenses in preeclampsia. Lipid peroxidation in preeclampsia. Pathophysiology 2005, 9:21-25.

11. Slater $D, A$ Alport $V$, Bennett $P$ : Changes in the expression of the type-2 but not the type-1 cyclo-oxygenase enzyme in chorion-decidua with the onset of labour. Br J Obstet Gynaecol 1998, 105:745-748.

12. Bennett PR, Slater DM: COX-2 expression in labour. Improved Non-Steroid Anti-Inflammatory Drugs Cox-2 Enzym Inhibitors Kluwer Academic Publishers, LancasterVane JR, Botting R 1996, 167-188.

13. Gibb W, Sun M: Localization of prostaglandin $\mathrm{H}$ synthase type 2 protein and mRNA in term human fetal membranes and decidua. $J$ Endocrinol 1996, 150:497-503

14. Silver R, Edwin S, Trautman M, Simmons D, Branch D, Dudley D, Mitchell M: Bacterial lipopolysaccharide-mediated fetal death. Production of a newly recognized form of inducible cyclooxygenase (COX-2) in murine decidua in response to lipopolysaccharide. J Clin Invest 1995, 95(2):725-731.

15. Akarasereenont $P$, Techatrisak K, Chotewuttakorn S, Thaworn A: The induction of cyclooxygenase-2 (COX-2) in cultured endothelial cells treated with serum from preeclampsia is mediated by interleukin- 6 . J Med Assoc Thai 1999, 82:876-884.

16. Wetzka B, Nusing R, Charnock-Jones DS, Schafer W, Zahradnik HP, Smith SK: Cyclooxygenase- 1 and -2 in human placenta and placental bed after normal and pre-eclamptic pregnancies. Human Reproduction 1997, 12:2313-2320

17. Yuan B, Ohyyama K, Bessho T, Toyoda H: Contribution of inducible nitric oxide synthase and cyclooxygenase-2 to apoptosis induction in smooth chorion trophoblast cells of human fetal membrane tissues. Biochem Biophys Res Commun 2006, 341:876-884.

18. Meziani F, Tesse A, David E, Martinez M, Wangesteen R, Schneider F, Andriantsitohaina $R$ : Shed membrane particles from preeclamptic women generate vascular wall inflammation and blunt vascular contractility. Am J Pathol 2006, 169:1473-1483.

19. Khan I, al-Yatama $\mathrm{M}$, Nandakumaran $\mathrm{M}$ : Expression of the $\mathrm{Na}(+)-\mathrm{H}+$ exchanger isoform-1 and cyclooxygenases in human placentas: their implications in preeclampsia. Biochem Mol Biol Int 1999, 47:715-722.

20. Polydorides AD, Kalish RB, Witkin SS, Baergen RN: A fetal cyclooxygenase-2 gene polymorphism is associated with placental malperfusion. Int J Gynecol Pathol 2007, 26:284-290.

21. Perkins DJ, Kremsner PG, Weinberg JB: Inverse relationship of plasma prostaglandin E2 and blood mononuclear cell cyclooxygenase-2 with disease severity in children with Plasmodium falciparum malaria. J Infect Dis 2001, 183:113-118.

22. Perkins DJ, Hittner JB, Mwaikambo ED, Granger DL, Weinberg JB, Anstey NM: Impaired systemic production of prostaglandin E2 in children with cerebral malaria. J Infect Dis 2005, 191:1548-1557.
23. Campbell WB, Haluska PV: Lipid derived autacoids: eicosanoids and platelet-activating factor. Goodman and Gilman's The pharmacological Basis of Therapeutics Mc-Graw-Hill, New YorkHardman, JG, Limbrid, LE, Molinoff, PB et al 1996, 601-616.

24. Bennett PR, Elder MG, Myatt $L$ : The effects of lipoxygenase metabolites of arachidonic acid on human myometrial contractility. Prostaglandins 1987, 33(6):837-844.

25. Spector AA, Gordon JA, Moore SA: Hydroxyeicosatetraenoic acids (HETEs). Prog Lipid Res 1988, 27:271-323.

26. Shellhaas CS, Coffman T, Dargie PJ, Killam AP, Kay HH: Intravillous eicosanoid compartmentalization and regulation of placental blood flow. J Soc Gynecol Investig 1997, 4:58-63.

27. Everts $B$, Wahrborg $P$, Hedner T: COX-2-Specific inhibitors-the emergence of a new class of analgesic and anti-inflammatory drugs. Clin Rheumatol 2000, 19:331-343.

28. Hausman N, Beharry K, Nishihara K, Akmal Y, Asrat T: Antenatal administration of celecoxib, a selective cyclooxygenase (COX)-2 inhibitor, appears to improve placental perfusion in the pregnant rabbit. Prostaglandins Other Lipid Mediat 2003, 70(3-4):303-315.

29. Sarr D, Marrama L, Gaye A, Dangou JM, Niang M, Mercereau-Puijalon O, Lehesran JY, Jambou R: High prevalence of placental malaria and low birth weight in Sahelian periurban area. Am J Trop Med Hyg 2006, 75:171-177.

30. CNLS: Bulletin Seroepidemiologique de surveillance du VIH \#11. Dakar, Senegal, CNLS 2004.

31. Bulmer JN, Rasheed FN, Francis N, Morrison L, Greenwood BM: Placental malaria. I. Pathological classification. Histopathology 1993, 22:211-218.

32. Livak KJ, Schmittgen TD: Analysis of relative gene expression data using real-time quantitative PCR and the 2(-Delta Delta C(T)) Method. Methods 2001, 25:402-408.

33. Perkins DJ, Moore JM, Otieno J, Shi YP, Nahlen BL, Udhayakumar V, Lal AA In vivo acquisition of hemozoin by placental blood mononuclear cells suppresses PGE2, TNF-alpha, and IL-10. Biochem Biophys Res Commun 2003, 311:839-846.

34. Keller CC, Hittner JB, Nti BK, Weinberg JB, Kremsner PG, Perkins DJ: Reduced peripheral PGE2 biosynthesis in Plasmodium falciparum malaria occurs through hemozoin-induced suppression of blood mononuclear cell cyclooxygenase-2 gene expression via an interleukin-10independent mechanism. Mol Med 2004, 10:45-54.

35. Prato M, Giribaldi G, Polimeni M, Gallo V, Arese P: Phagocytosis of hemozoin enhances matrix metalloproteinase- 9 activity and TNF-alpha production in human monocytes: role of matrix metalloproteinases in the pathogenesis of falciparum malaria. J Immunol 2005, 175:6436-6442.

36. Prato M, Gallo V, Giribaldi G, Arese P: Phagocytosis of haemozoin (malarial pigment) enhances metalloproteinase- 9 activity in human adherent monocytes: role of IL-1beta and 15-HETE. Malar J 2008, 7:157.

37. Coban C, Ishii KJ, Kawai T, Hemmi H, Sato S, Uematsu S, Yamamoto M, Takeuchi O, Itagaki S, Kumar N, Horii T, Akira S: Toll-like receptor 9 mediates innate immune activation by the malaria pigment hemozoin. $J$ Exp Med 2005, 201:19-25.

38. Ismail MR, Ordi J, Menendez C, Ventura PJ, Aponte JJ, Kahigwa E, Hirt R, Cardesa A, Alonso PL: Placental pathology in malaria: a histological, immunohistochemical, and quantitative study. Hum Pathol 2000, 31:85-93.

39. Lorenz M, Slaughter HS, Wescott DM, Carter SI, Schnyder B, Dinchuk JE, Car BD: Cyclooxygenase-2 is essential for normal recovery from 5fluorouracil-induced myelotoxicity in mice. Exp Hematol 1999, 27:1494-1502.

40. Suguitan AL Jr, Cadigan TJ, Nguyen TA, Zhou A, Leke RJ, Metenou S, Thuita L, Megnekou R, Fogako J, Leke RG, Taylor DW: Malaria-associated cytokine changes in the placenta of women with pre-term deliveries in Yaounde, Cameroon. Am J Trop Med Hyg 2003, 69:574-581.

41. Kabyemela ER, Muehlenbachs A, Fried M, Kurtis JD, Mutabingwa TK, Duffy PE: Maternal peripheral blood level of IL-10 as a marker for inflammatory placental malaria. Malar J 2008, 7:26.

42. Hanna N, Bonifacio L, Weinberger B, Reddy P, Murphy S, Romero R, Sharma S: Evidence for interleukin-10-mediated inhibition of cyclooxygenase-2 expression and prostaglandin production in preterm human placenta. Am J Reprod Immunol 2006, 55:19-27.

43. de Waal Malefyt R, Abrams J, Bennett B, Figdor CG, de Vries JE: Interleukin 10(IL-10) inhibits cytokine synthesis by human monocytes: an 
autoregulatory role of IL-10 produced by monocytes. J Exp Med 1991, 174:1209-1220.

44. Hanna N, Bonifacio L, Reddy P, Hanna I, Weinberger B, Murphy S, Laskin D, Sharma S: IFN-gamma-mediated inhibition of COX-2 expression in the placenta from term and preterm labor pregnancies. Am J Reprod Immunol 2004, 51:311-318.

45. Su EJ, Lin ZH, Zeine R, Yin P, Reierstad S, Innes JE, Bulun SE: Estrogen receptor-beta mediates cyclooxygenase-2 expression and vascular prostanoid levels in human placental villous endothelial cells. Am J Obstet Gynecol 2009, 200:e421-428.

46. Setty BN, Dampier CD, Stuart MJ: Arachidonic acid metabolites are involved in mediating red blood cell adherence to endothelium. J Lab Clin Med 1995, 125:608-617.

doi:10.1186/1475-2875-9-45

Cite this article as: Sarr et al:: Chronic infection during placental malaria is associated with up-regulation of cycloxygenase-2. Malaria Journal 2010 9:45.

\section{Submit your next manuscript to BioMed Central} and take full advantage of:

- Convenient online submission

- Thorough peer review

- No space constraints or color figure charges

- Immediate publication on acceptance

- Inclusion in PubMed, CAS, Scopus and Google Scholar

- Research which is freely available for redistribution

Submit your manuscript at www.biomedcentral.com/submit 